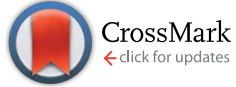

Cite this: J. Mater. Chem. A, 2015, 3, 3901

Received 19th December 2014

Accepted 5th January 2015

DOI: $10.1039 / c 4 t a 07022 d$

www.rsc.org/MaterialsA

\section{From molecular copper complexes to composite electrocatalytic materials for selective reduction of $\mathrm{CO}_{2}$ to formic acid $\uparrow$}

\author{
Tran Ngoc Huan, ${ }^{a}$ Eugen. S. Andreiadis, ${ }^{a b}$ Jonathan Heidkamp, ${ }^{f}$ Philippe Simon, ${ }^{b}$ \\ Etienne Derat, ${ }^{\mathrm{c}}$ Saioa Cobo, ${ }^{\mathrm{d}}$ Guy Royal, ${ }^{\mathrm{d}}$ Arno Bergmann, ${ }^{\mathrm{e}}$ Peter Strasser, ${ }^{\mathrm{e}}$ \\ Holger Dau, ${ }^{f}$ Vincent Artero*a and Marc Fontecave ${ }^{\star b}$
}

\begin{abstract}
The development of new energy storage technologies is central to solving the challenges facing the widespread use of renewable energies. An option is the reduction of carbon dioxide $\left(\mathrm{CO}_{2}\right)$ into carbonbased products which can be achieved within an electrochemical cell. Future developments of such processes depend on the availability of cheap and selective catalysts at the electrode. Here we show that a unique well-characterized active electrode material can be simply prepared via electrodeposition from a molecular copper complex precursor. The best performances, namely activity (150 $\mathrm{mV}$ onset overpotential and $1 \mathrm{~mA} \mathrm{~cm}{ }^{-2}$ current density at $540 \mathrm{mV}$ overpotential), selectivity (90\% faradaic yield) and stability for electrocatalytic reduction of $\mathrm{CO}_{2}$ into formic acid in $\mathrm{DMF} / \mathrm{H}_{2} \mathrm{O}(97: 3 \mathrm{v} / \mathrm{v})$ have been obtained with the $[\mathrm{Cu}(\mathrm{cyclam})]\left(\mathrm{ClO}_{4}\right)_{2}$ complex (cyclam $=1,4,8,11$-tetraazacyclotetradecane) as the precursor. Remarkably the organic ligand of the $\mathrm{Cu}$ precursor remains part of the composite material and the electrocatalytic activity is greatly dependent on the nature of that organic component.
\end{abstract}

$\mathrm{CO}_{2}$ transformation into energy-dense organic compounds is currently emerging as an exciting strategy in the context of the development of new energy technologies. ${ }^{1-9}$ It indeed (i) allows storage of intermittent and diluted renewable energy sources (wind and sun) in the form of concentrated chemical energy (chemical fuels and industrial chemicals conventionally derived from petroleum), (ii) may contribute to limit the accumulation of $\mathrm{CO}_{2}$, a gas with greenhouse effect, in the atmosphere, and (iii) generates a global carbon-neutral and circular energy system. Practically this can be achieved through electro-reduction of $\mathrm{CO}_{2}$ within electrochemical cells ideally powered by wind turbines or photovoltaic panels. ${ }^{10}$ Unfortunately the reactions

${ }^{a}$ Laboratoire de Chimie et Biologie des Métaux, Univ. Grenoble Alpes, CNRS UMR 5249, CEA, 17 rue des martyrs, 38054 Grenoble cedex 9, France. E-mail: vincent. artero@cea.fr

${ }^{b}$ Laboratoire de Chimie des Processus Biologiques, Collège de France, Université Pierre et Marie Curie, CNRS UMR 8229, 11 Place Marcelin Berthelot, 75005 Paris, France. E-mail: marc.fontecave@college-de-france.fr

'Sorbonne Universités, UPMC Univ. Paris 06, UMR 8232, Institut Parisien de Chimie Moléculaire, 75005 Paris, France

${ }^{d}$ Univ. Grenoble Alpes, CNRS, Département de Chimie Moléculaire, UMR 5250, 38000 Grenoble, France

${ }^{e}$ The Electrochemical Energy, Catalysis and Materials Science Laboratory, Department of Chemistry, Chemical Engineering Division, Technical University Berlin, Straße des 17. Juni 124, 10623 Berlin, Germany

${ }^{f}$ Fachbereich Physik, Freie Universität Berlin, Arnimallee 14, 14195 Berlin, Germany

$\dagger$ Electronic supplementary information (ESI) available. See DOI: 10.1039/c4ta07022d involve multiple electrons. Therefore they are generally limited by very low kinetics which translate into large overpotentials (thus with significant energy losses) as well as by low selectivity since a variety of $\mathrm{CO}_{2}$-derived products $(\mathrm{CO}, \mathrm{HCOOH}$, oxalate and, to lower extents, methanol or hydrocarbons) together with molecular hydrogen can be produced at the same time. ${ }^{6}$ The latter derives from the parallel reduction of protons required for $\mathrm{CO}_{2}$ activation.

A key technological challenge thus resides in the development of active electro-catalysts, for reducing $\mathrm{CO}_{2}$ with significant current densities at low overpotentials, in reactions displaying high selectivity and faradaic yield for a given $\mathrm{CO}_{2}$ derived product. In particular, the production of liquid fuels such as formic acid ${ }^{11}$ or methanol, ${ }^{12}$ fitting into existing infrastructure for fuel transportation and distribution, is an attractive target. A number of electrocatalytic materials have been assayed under alkaline aqueous carbonate solutions. ${ }^{6}$ However, recent studies ${ }^{\mathbf{1 3 - 1 7}}$ were carried out in non-aqueous media such as organic solvents and ionic liquids, since they offer larger $\mathrm{CO}_{2}$ solubility and an easy control of $\mathrm{H}_{2}$ evolution through tuning of water concentration. This allowed the development of novel materials for example based on $\mathrm{MoO}_{2},{ }^{16} \mathrm{Bi}^{\mathbf{1 3 , 1 4}}$ or B-doped diamond ${ }^{15}$ reducing $\mathrm{CO}_{2}$ at low overpotential with good selectivity. Molecular metal complexes ${ }^{\mathbf{1 , 2 , 5 , 6}}$ constitute another interesting class of such selective electrocatalysts ${ }^{\mathbf{1 8}}$ operating at low overpotential in organic solvents. Their activity can be synthetically tuned through ligand variations. To date, only one copper 
coordination compound has been reported as an electrocatalyst for $\mathrm{CO}_{2}$ reduction. ${ }^{19}$ In the course of a study aimed at identifying novel $\mathrm{Cu}$-based molecular $\mathrm{CO}_{2}$-reducing catalysts, we found that a composite material could be electrodeposited on the electrode. This Cu-based material, which has been extensively characterized and shown to retain the organic ligand from the copper precursor, displays remarkable activity, selectivity and stability for electrocatalytic reduction of $\mathrm{CO}_{2}$ into formic acid, a product of wide industrial applications.

\section{Results and discussion}

Continuous voltamperometric cycling at a fluorine-doped tin oxide (FTO) electrode dipped into a $\mathrm{CO}_{2}$-saturated solution of $1.3 \mathrm{mM}[\mathrm{Cu}($ cyclam $)]\left(\mathrm{ClO}_{4}\right)_{2}($ cyclam $=1,4,8,11$-tetraazacyclotetradecane) in DMF containing 3\% water and supporting electrolyte $\left(0.1 \mathrm{M} n-\mathrm{Bu}_{4} \mathrm{NBF}_{4}\right)$ triggered the appearance and growth of a chemically-reversible signal with both an oxidation wave and a reduction wave, at $E_{\mathrm{pa}}=0.58 \mathrm{~V} v s$. $\mathrm{Fc}^{+} / \mathrm{Fc}$ and $E_{\mathrm{pc}}=-0.98$ $\mathrm{V} v$ s. $\mathrm{Fc}^{+} / \mathrm{Fc}$, (black trace in Fig. 1) respectively, and tentatively assigned to a Cu-based process. ${ }^{\mathbf{2 0 , 2 1}}$ This feature revealed an electrodeposition reaction in agreement with the observation of a blue material at the surface of the electrode (inset in Fig. 1, in the following "blue material" will be used to name this novel $\mathrm{Cu}$-based electrodeposit). In addition, the cyclic voltammograms display an intense current wave, with an onset at $-1.60 \mathrm{~V}$ vs. $\mathrm{Fc}^{+} / \mathrm{Fc}$, reflecting an electrocatalytic process. Importantly, scanning over this electrocatalytic process was a requirement for the deposition of the blue material. No electrodeposition and no electrocatalytic wave could be observed when $\mathrm{CO}_{2}$ or water was removed from the reaction mixture, thus strongly suggesting electrocatalytic $\mathrm{CO}_{2}$ reduction. The cyclic voltammogram (red trace in Fig. 1) of the modified electrode was then recorded independently under similar conditions but in the

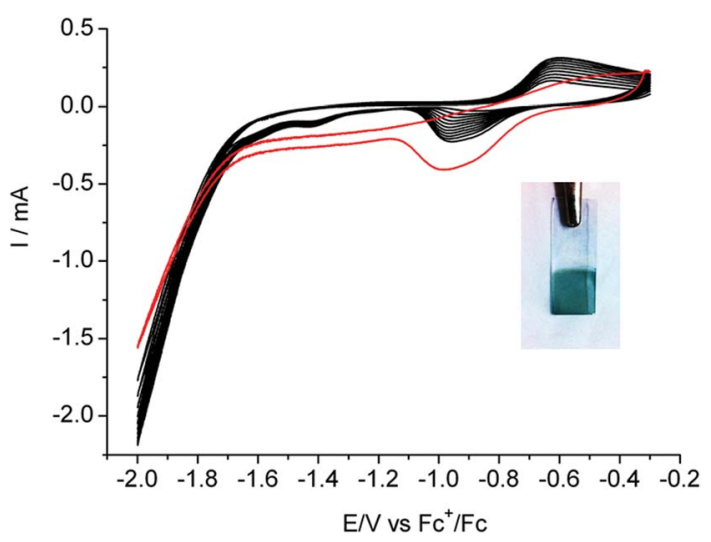

Fig. 1 Cyclic voltammograms recorded on a FTO electrode $\left(1 \mathrm{~cm}^{2}\right)$ in $\mathrm{CO}_{2}$-saturated $\mathrm{DMF} / \mathrm{H}_{2} \mathrm{O}(97: 3 \mathrm{v} / \mathrm{v})$ solution and $0.1 \mathrm{M} n-\mathrm{Bu}_{4} \mathrm{NBF}_{4}$. The black trace was recorded in the presence of $1.3 \mathrm{mM}$ $[\mathrm{Cu}(\mathrm{cyclam})]\left(\mathrm{ClO}_{4}\right)_{2}$. The inset shows a picture of the electrode modified with the blue material obtained after recording the black trace. The red trace is obtained under similar conditions but in the absence of $[\mathrm{Cu}(\mathrm{cyclam})]^{2+}$ using the electrode after electrodeposition and washing of the blue material. absence of $[\mathrm{Cu}(\text { cyclam })]^{2+}$. It retained the two above mentioned features, which remained unchanged during tens of cycles. Remarkably, no change in the intensity of the electrocatalytic wave was observed upon repeated $\mathrm{N}_{2} / \mathrm{CO}_{2}$ saturation cycles (Fig. S1†).

The preparation of the blue material was also achieved from the same $\mathrm{CO}_{2}$-saturated $\mathrm{DMF} / \mathrm{H}_{2} \mathrm{O}(97: 3 \mathrm{v} / \mathrm{v})$ solution containing $1.3 \mathrm{mM}[\mathrm{Cu}(\text { cyclam })]^{2+}$ and $0.1 \mathrm{M} n-\mathrm{Bu}_{4} \mathrm{NBF}_{4}$ but using a potentiostatic method. This allows optimization of the catalytic properties of the blue material via variations of the applied potential and the charge passed during electrodeposition. Each modified electrode was then assayed for $\mathrm{CO}_{2}$ reduction during electrolysis of a $\mathrm{CO}_{2}$-saturated $[\mathrm{Cu}(\text { cyclam })]^{2+}$-free $\mathrm{DMF} / \mathrm{H}_{2} \mathrm{O}$ $(97: 3 \mathrm{v} / \mathrm{v})$ solution at $-2.0 \mathrm{~V} v s$. $\mathrm{Fc}^{+} / \mathrm{Fc}$, with subsequent monitoring of the formation of the following products: in the gas phase, $\mathrm{CO}$, methane and other volatile hydrocarbons as well as $\mathrm{H}_{2}$ were monitored by gas chromatography; in the liquid phase, methanol was monitored by gas chromatography, formaldehyde by a colorimetric test, while formic acid, oxalate and glyoxylate were assayed by ion-exchange chromatography (see the ESI $\dagger$ ). In all cases only formic acid and $\mathrm{H}_{2}$ could be detected and quantified. Working with $3 \%$ water during electrolysis was critical. Indeed, electrolysis carried out in the absence of water gave almost no current (Fig. S2 $\dagger$ ), while in the presence of $10 \%$ water a larger current density (Fig. $\mathrm{S} 2 \dagger$ ) but also a larger formation of $\mathrm{H}_{2}$ (faradaic yields: $60 \%$ for $\mathrm{H}_{2}$ and $40 \%$ for formic acid) were obtained. This reflects, in one hand, the requirement of water as a source of protons for $\mathrm{CO}_{2}$ reduction and, in another hand, the competition between proton and $\mathrm{CO}_{2}$ reduction processes. It is also consistent with the $\mathrm{H}$ atoms of $\mathrm{H}_{2}$ and formic acid deriving from $\mathrm{H}_{2} \mathrm{O}$ exclusively.

From these optimization experiments, it resulted that the best results in terms of current density, stability and faradaic yield for potentiostatic $\mathrm{CO}_{2}$ conversion into formic acid (blue trace in Fig. 2a and blue dot in Fig. 2b) were obtained with a blue material resulting from passage of a total charge $(Q)$ of $4 \mathrm{C}$ $\mathrm{cm}^{-2}$ during the electrodeposition step, using $[\mathrm{Cu}(\text { cyclam })]^{2+}$ as the precursor, with an applied potential of $-2.0 \mathrm{~V} v s . \mathrm{Fc}^{+} / \mathrm{Fc}$. Lower and larger $Q$ values resulted in lower faradaic yields (Fig. 2b) and less stable currents (Fig. 2a). Electrodeposition at lower potentials (Fig. S3†) resulted in less active deposits. Such an optimum might result from the balance between the charge needed to deposit enough active material and the decrease in conductivity expected for thick electrode films. Furthermore $\mathrm{CH}_{3} \mathrm{CN} / \mathrm{H}_{2} \mathrm{O}$ mixtures were also tested as the solvent but resulted into less active deposits (Fig. S4 $\dagger$ ) and electrolysis in this solvent mixture gave very low faradaic yields in formic acid $(<30 \%)$. Using two different copper complexes, namely $\left[\mathrm{Cu}(\text { terpy })_{2}\right]^{2+}$ or $[\mathrm{Cu}(\mathrm{TACN})]^{2+}(\mathrm{TACN}=1,4,7$-triazacyclononane) as precursors under the established optimal conditions also led to stable blue electrodeposits, however much less active and less selective (Fig. S5†). Furthermore, substitution of a simple copper(II) salt for $[\mathrm{Cu}(\text { cyclam })]^{2+}$ during electrodeposition led to the formation of a blue deposit with similar electroactive surface area, however less active and stable (Fig. S6†). 
a)

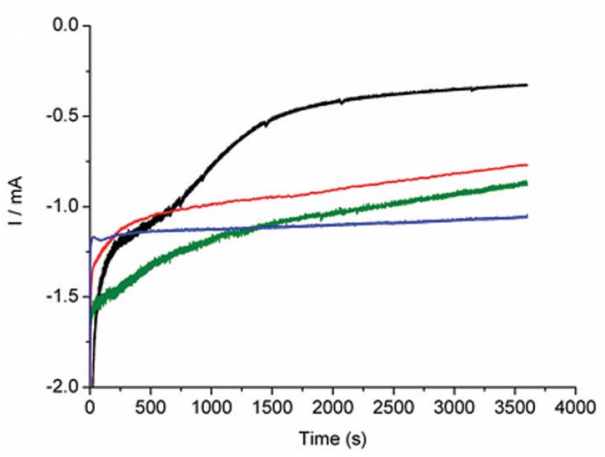

b)

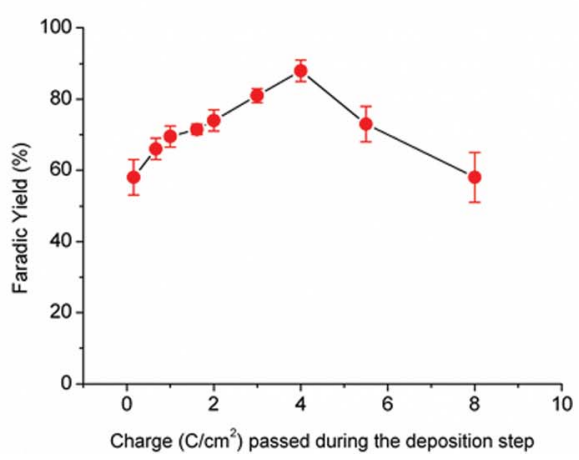

Fig. 2 (a) Evolution of the electrocatalytic current during potentiostatic $\mathrm{CO}_{2}$ reduction assay at $-2.0 \mathrm{Vvs}$. $\mathrm{Fc} / \mathrm{Fc}$ in $\mathrm{DMF} / \mathrm{H}_{2} \mathrm{O}(97: 3 \mathrm{v} / \mathrm{v})$ solution measured on FTO electrodes modified with the blue material $\left(1 \mathrm{~cm}^{2}\right)$ from [Cu(cyclam) $]^{2+}$. The electrodes differed by the quantity of charge passed during the deposition step: $0.2 \mathrm{C}$ (black trace), 1.6 C (red trace), $4.0 \mathrm{C}$ (blue trace) and $8 \mathrm{C}$ (green trace); (b) faradaic yield for formation of formic acid during potentiostatic $\mathrm{CO}_{2}$ reduction assays $(1 \mathrm{~h})$ at $-2.0 \mathrm{~V}$ vs. Fc $/ \mathrm{Fc}$ in $\mathrm{DMF} / \mathrm{H}_{2} \mathrm{O}(97: 3 \mathrm{v} / \mathrm{v})$ solution measured on modified $\mathrm{FTO}$ electrodes $\left(1 \mathrm{~cm}^{2}\right) . \mathrm{H}_{2}$ formation accounts for the complement of the faradaic yield to $100 \%$. The blue dot shows the conditions for optimal yield. Errors bars indicate variations obtained during at least 5 experiments for each charge value.

In conclusion of these studies electrolysis of a $\mathrm{CO}_{2}$-saturated $[\mathrm{Cu}(\text { cyclam })]^{2+}$-free solution at $-2.0 \mathrm{~V} v \mathrm{~s}$. $\mathrm{Fc}^{+} / \mathrm{Fc}$ using our best material generated a current density of about $1.3 \mathrm{~mA} \mathrm{~cm}^{-2}$ (blue trace in Fig. 2a) which only slowly decreased with time $\left(0.8 \mathrm{~mA} \mathrm{~cm}^{-2}\right.$ after 10 hours of continuous operation, Fig. S7 $\left.\dagger\right)$. Formic acid was produced with a faradaic yield of $88 \pm 3 \%, \mathrm{H}_{2}$ evolution accounting for the complement. No formic acid production could be detected when a blank FTO electrode was used under the same conditions (Fig. S7†). Interestingly, the electrodeposited material proved significantly more active, with larger current density values at steady state and higher faradaic yield for formic acid production, than an electro-polished polycrystalline $\mathrm{Cu}$ plate, a metallic $\mathrm{Cu}$ deposit $^{22}$ or electrodeposited copper(I) oxide ${ }^{23}$ with comparable electroactive surface areas, determined via standard methods (Fig. S8 $\dagger$ ).

Fig. 3 shows the Tafel plot of the blue material derived from linear sweep voltammetry measurement at a scan rate of $0.5 \mathrm{mV} \mathrm{s}^{-1}$ in a $\mathrm{CO}_{2}$-saturated $\mathrm{DMF} / \mathrm{H}_{2} \mathrm{O}(97 / 3 \mathrm{v} / \mathrm{v})$ solution. Determination of overpotential values requests calculation of the standard potential for $\mathrm{CO}_{2} / \mathrm{HCOOH}$ in $\mathrm{DMF} / \mathrm{H}_{2} \mathrm{O}$ solution, a parameter surprisingly not available in the literature value whereas the standard potential of the $\mathrm{CO}_{2} / \mathrm{CO}$ couple in $\mathrm{CH}_{3} \mathrm{CN}$ / $\mathrm{H}_{2} \mathrm{O}$ and DMF/ $\mathrm{H}_{2} \mathrm{O}$ media was recently reported. ${ }^{18}$ In the ESI $\dagger$ we indicate how our calculations led to a value of $-0.78 \mathrm{~V} v s$. NHE. For that purpose, solvation enthalpies for formic acid in various solvents were computed using the SMD implicit solvation method, ${ }^{24}$ the M05-2X functional and the TZVP basis. The potential of the $\mathrm{Fc}^{+} / \mathrm{Fc}$ couple in DMF $\left(E^{\mathrm{DMF}}\left(\mathrm{Fc}^{+} / \mathrm{Fc}\right)\right)$ is $0.57 \pm$ $0.02 \mathrm{~V} v s$. NHE when taking into account the interliquid junction potential. ${ }^{18}$ This value was used to convert experimental electrochemical potential values into overpotential values in Fig. 3 (See the ESI $\dagger$ ). Catalytic onset potential is $-1.5 \mathrm{Vvs.} \mathrm{Fc}^{+} / \mathrm{Fc}$ which corresponds to an overpotential requirement of about $150 \mathrm{mV}$. The Tafel data are linear in the range $\eta=200-400 \mathrm{mV}$ with exchange current density of $10^{-1.3} \mathrm{~mA} \mathrm{~cm} \mathrm{~cm}^{-2}$ and slope of $120 \mathrm{mV}$ per decade, a value consistent with a mechanism in

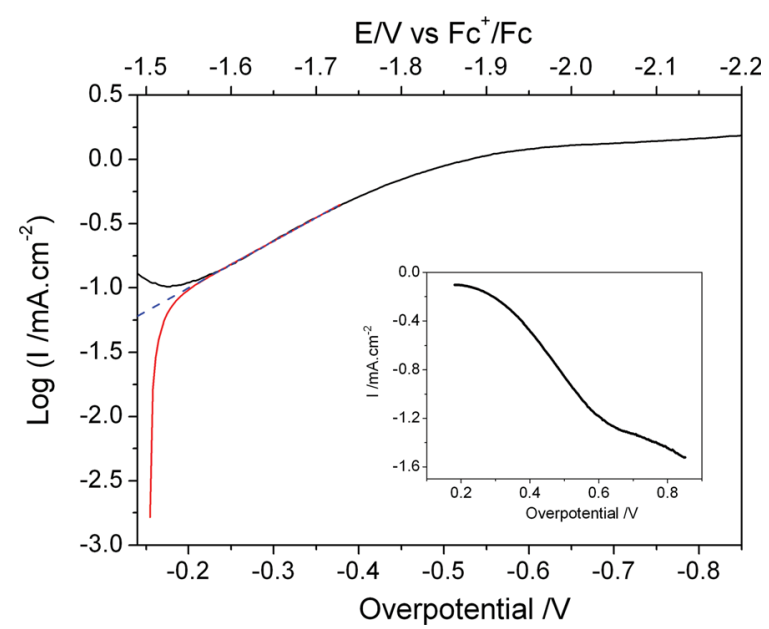

Fig. 3 Tafel plot obtained from linear sweep voltammetry experiments recorded at $0.5 \mathrm{mV} \mathrm{s}^{-1}$ on a blue material modified electrode $\left(1 \mathrm{~cm}^{2}\right)$ obtained from [Cu(cyclam) $]^{2+}$ in a $\mathrm{CO}_{2}$-saturated solution of $\mathrm{DMF} / \mathrm{H}_{2} \mathrm{O}$ (97: $3 \mathrm{v} / \mathrm{v}+0.1 \mathrm{Mn}-\mathrm{Bu}_{4} \mathrm{NBF}_{4}$ ). The corresponding polarization curve is shown in the inset. See the ESI $\uparrow$ for the determination of the overpotential for formic acid production.

which the first electron transfer to adsorbed $\mathrm{CO}_{2}$ is the ratedetermining step. ${ }^{25}$ The catalytic current then reaches a plateau $\left(\sim 1 \mathrm{~mA} \mathrm{~cm}^{-2}\right.$ ) for overpotentials larger than $540 \mathrm{mV}$ and corresponding to the above-mentioned optimized conditions.

Characterization of the blue material on the most active electrode was carried out using a variety of methods. First, chemical analysis (see methods in the ESI $\dagger$ ) revealed the presence of carbonate or bicarbonate $\left(2.0 \pm 0.2 \mu \mathrm{mol} \mathrm{cm}^{-2}\right)$, formate $\left(1.6 \pm 0.1 \mu \mathrm{mol} \mathrm{cm} \mathrm{cm}^{-2}\right), \mathrm{Cu}$ ions $\left(12.5 \pm 0.2 \mu \mathrm{mol} \mathrm{cm}^{-2}\right)$ and cyclam $\left(4 \pm 2 \mathrm{nmol} \mathrm{cm}^{-2}\right) .{ }^{26}$ When $\left[\mathrm{Cu}(\text { terpy })_{2}\right]^{2+}$ or $[\mathrm{Cu}(\mathrm{TACN})]^{2+}$ were used as precursors, the deposits were also shown to contain a small amount of the organic ligand $(2 \pm 1$ and $4 \pm 2 \mathrm{nmol} \mathrm{cm} \mathrm{cm}^{-2}$ respectively). Scanning electronic microscopy (SEM) showed regions where the FTO electrode is 
coated by nanoparticles ( $100 \mathrm{~nm}$ in diameter, Fig. 4) surrounded by significantly larger particles (few $\mu \mathrm{m}$ in diameter) consistent with a deposit thickness of $1.5 \mu \mathrm{m}$ as determined by atomic force microscopy (AFM) (Fig. S9†). Optical microscopy confirmed this observation with the large particles and the background coating appearing as red and blue respectively. Energy Dispersive X-ray (EDX) spectroscopy indicated the presence of mainly $\mathrm{Cu}$ and $\mathrm{O}$ atoms in the large particles while the nanoparticles contained higher amounts of $\mathrm{C}, \mathrm{N}$ and $\mathrm{O}$ with regard to $\mathrm{Cu}$ atoms (Fig. S10†). X-ray photoelectron spectroscopy (XPS) analysis (Fig. 4) confirmed the presence of carbonbased material: a broad peak with binding energies from 280 to $287 \mathrm{eV}$, in the $\mathrm{C} 1 \mathrm{~s}$ orbital region, could be simulated with a mixture of $\mathrm{C}-\mathrm{N}, \mathrm{C}-\mathrm{O}, \mathrm{C}-\mathrm{H}$ and $\mathrm{C}=\mathrm{O}$ features. Nitrogen was also observed as a double peak between 394 and $400 \mathrm{eV}$ in the N 1s region, likely reflecting a secondary amine as found in the cyclam ligand and quaternary ammonium ions from the supporting electrolyte. Finally analysis of the $\mathrm{Cu} 2 \mathrm{p}_{1 / 2}$ region revealed the presence of $\mathrm{Cu}(\mathrm{I})$, in the form of $\mathrm{Cu}_{2} \mathrm{O}$, and/or metallic copper, together with $\mathrm{Cu}(\mathrm{II})$, potentially coordinated to formate or carbonate/bicarbonate as found in some coordination polymers. ${ }^{27} \mathrm{X}$-ray absorption spectra collected at the copper K-edge indicate the presence of three contributions to the blue catalytic film. The main maximum of the XANES spectrum (around $8997 \mathrm{eV}$ in Fig. 5A) is indicative of light ligand atoms $(\mathrm{O} / \mathrm{N} / \mathrm{C})$; its low intensity renders octahedral coordination unlikely. The pronounced shoulder at $8982 \mathrm{eV}$ suggests a major fraction of $\mathrm{Cu}(\mathrm{I})$ ions coordinated by two light ligands, as found in $\mathrm{Cu}_{2} \mathrm{O}$. By simulations we determined about $20 \%$ of copper metal (Fig. 5B) and about $30 \%$ of $\mathrm{Cu}$ (II) ions (Fig. 5A), likely coordinated by four light atoms $(\mathrm{O} / \mathrm{N} / \mathrm{C})$; comparison with various $\mathrm{CuO}$ and $\mathrm{Cu}(\mathrm{II})$ compounds did not allow a more precise speciation of the latter (Fig. S11†). The remaining contribution was identified as $\mathrm{Cu}(\mathrm{I})$ ions, most likely coordinated by two light atoms $(\mathrm{O} / \mathrm{N} / \mathrm{C})$. Regarding its local structure, the $\mathrm{Cu}(\mathrm{I})$ material could resemble copper(I) oxide $\left(\mathrm{Cu}_{2} \mathrm{O}\right)$, but the long-range order

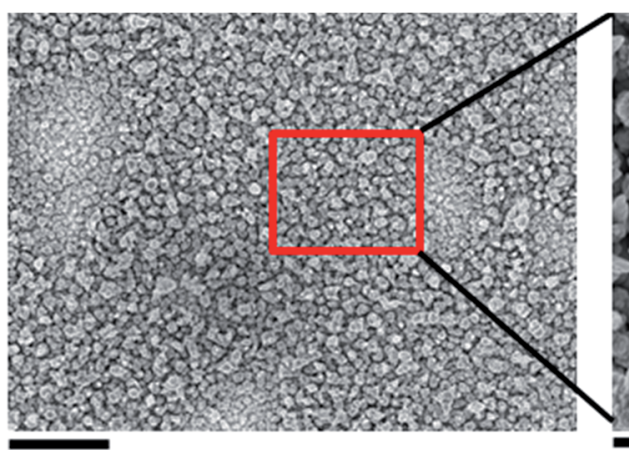

$\overline{1 \mu \mathrm{m}}$
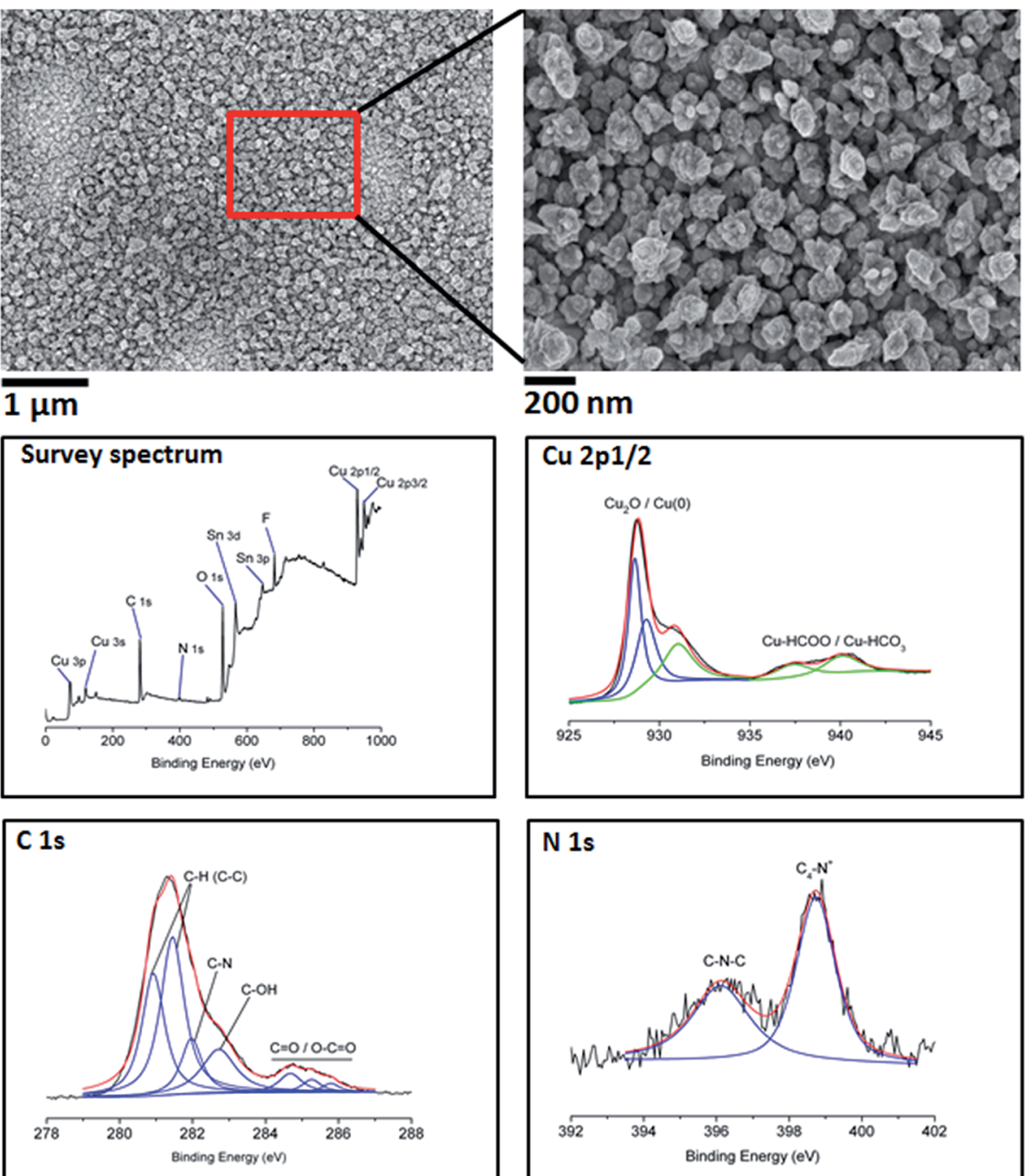

Fig. 4 Top: scanning electron micrograph of the blue material obtained from [Cu(cyclam) $]^{2+}$ (left) with focus on the background nanoparticulate coating (right). Middle and bottom: XPS survey (middle-left), $\mathrm{Cu}_{2 \mathrm{p}}$ (middle-right), $\mathrm{C}_{1 \mathrm{~s}}$ (bottom-left) and $\mathrm{N}_{1 \mathrm{~s}}$ (bottom-right) core levels spectra of blue material deposited onto FTO; the black traces correspond to experimental data, the red traces to the simulated spectra obtained from the sum of the blue and green traces. 

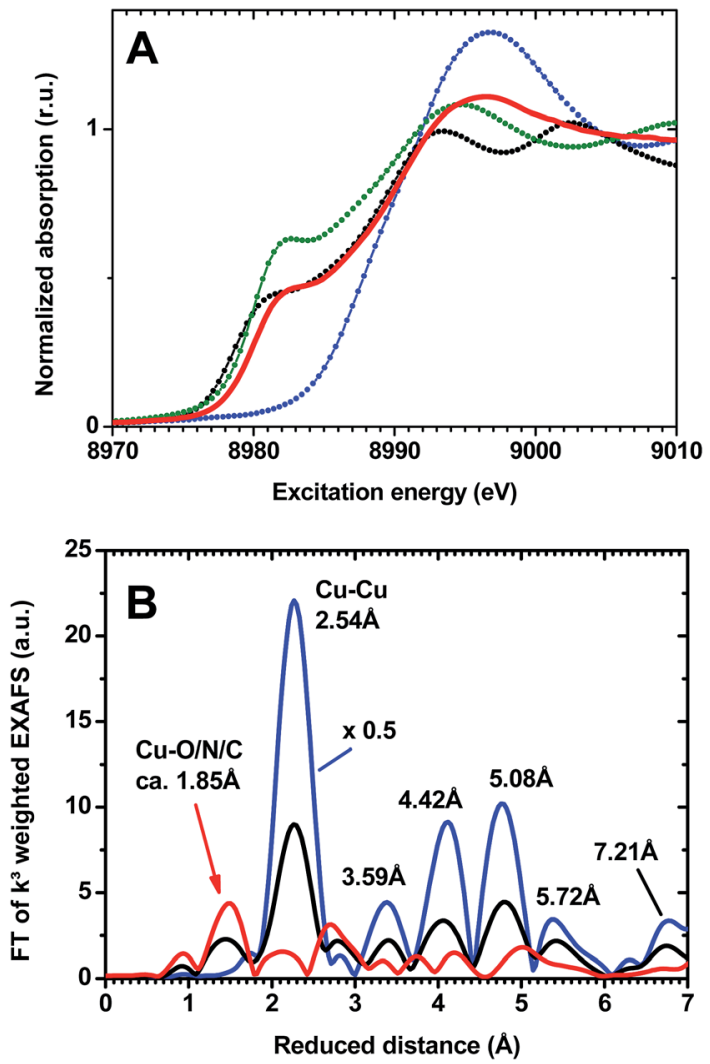

Fig. 5 Copper K-edge X-ray absorption spectra of the Cu-based blue material obtained from [Cu(cyclam) $]^{2+}$ and of reference materials. (A) XANES region of the spectrum (red trace, Cu-based material, deposition of $1 \mathrm{C} \mathrm{cm}^{-2}$; black trace, Cu metal foil; green trace, $\mathrm{Cu}($ () oxide, $\mathrm{Cu}_{2} \mathrm{O}$; blue trace, $\mathrm{Cu}\left({ }_{1}\right)$ oxalate). The spectrum of the blue material can be described by a linear combination of the shown $\mathrm{Cu}$ references (about 20\% Cu metal, 50\% Cu(I) oxide and 30\% Cu(॥) salt). (B) Fouriertransforms of $k^{3}$-weighted EXAFS spectra (black trace, blue material; blue trace, Cu metal foil, its FT amplitudes were multiplied by 0.5 ; red trace, blue material after correction for a metal contribution of $20 \%$. The metal peaks are labeled by the corresponding $\mathrm{Cu}-\mathrm{Cu}$ distance; the non-metallic peak of the blue material (red arrow) can be assigned to $\mathrm{Cu}-\mathrm{O} / \mathrm{N} / \mathrm{C}$ coordination.

of crystalline $\mathrm{Cu}_{2} \mathrm{O}$ was not detectable in the EXAFS (lowamplitude FT peaks at longer distance in metal-corrected spectra; Fig. S12 $\dagger$ ). The average distance of about $1.86 \AA$ of the $\mathrm{Cu}$-ligand distance as determined by EXAFS simulations of the metal-corrected spectra confirms a mixture of $\mathrm{Cu}(\mathrm{I}) \mathrm{L}_{2}$ and $\mathrm{Cu}$ (II) $\mathrm{L}_{4}$ coordination geometries $(\mathrm{L}=\mathrm{O} / \mathrm{N} / \mathrm{C}$, Table $\mathrm{S} 1 \dagger)$.

We finally performed XRD measurements on the Cu-based blue materials (See Fig. 2 for corresponding catalytic activities). On the films grown with a passed charge less than $1 \mathrm{C} \mathrm{cm}^{-2}$, no crystalline phase could be detected. By contrast, thicker films contain both crystalized metallic copper and copper(I) oxide. For example, films grown with a passed charge of $4 \mathrm{C} \mathrm{cm}^{-2}$ contain $\sim 20 \mathrm{~nm}$ metallic copper crystallites and $\mathrm{Cu}_{2} \mathrm{O}$ crystallites with size $<5 \mathrm{~nm}$ (Fig. S13 $\dagger$ ). This clearly suggests an influence of the thickness and structuration of the films on the performances.

The active blue material can thus be described as a composite mixture of metallic copper, copper(I) oxide $\left(\mathrm{Cu}_{2} \mathrm{O}\right)$ and an insoluble $\mathrm{Cu}(\mathrm{II})$-based material as well as the organic ligand of the molecular $\mathrm{Cu}$-based precursor. The most striking feature of this material resides in the fact that the activity is very much dependent on the choice of this ligand. On the other hand the best performances were obtained with films containing $\mathrm{Cu}$ and $\mathrm{Cu}_{2} \mathrm{O}$ crystallites. Overall, this indicates that the blue material is unique in deriving its catalytic properties from synergetic contributions of its different, organic and inorganic, components. Considering the complex nature of the composite catalyst, further experiments are needed to understand its surface reactivity and reaction mechanisms. Whether a supported homogeneous catalysis, based on ligand-bound copper ions somehow integrated in the material or a metallic copper surface-based process, facilitated by the presence of organic molecules as reported in the case of cobalt-based water oxidizing catalytic materials, ${ }^{28-30}$ remains an open question. In the first case formic acid formation is likely to derive from $\mathrm{CO}_{2}$ insertion into a metal-hydride intermediate. ${ }^{31}$ In the second case, the mechanism is likely to involve an adsorbed $\mathrm{CO}_{2}{ }^{--}$ intermediate. ${ }^{25}$ More specifically, the exact role of the organic ligand in the activity of the blue material is intriguing. It might: (i) promote $\mathrm{Cu}$ active sites by coordination; (ii) participate in proton transfers as pendant amine functions do within electrocatalysts for $\mathrm{H}^{+} / \mathrm{H}_{2}$ interconversion ${ }^{32}$ or formate dehydrogenation; ${ }^{33}$ (iii) capture $\mathrm{CO}_{2}$ and increase its local surface concentration. ${ }^{34,35}$

\section{Conclusion}

We have described a novel hybrid material, electrocatalytically active for the reduction of $\mathrm{CO}_{2}$. This material is promising for the following reasons, on route towards implementation of this new material into practical electrochemical cells:

- Its preparation through electrodeposition from a simple $\mathrm{Cu}$ (II) coordination complex is both straightforward and costeffective.

- It exhibits high catalytic activity at moderate overpotentials. The overpotential requirement is $\sim 150 \mathrm{mV}$. It thus compares well with the recently described Bi-based material selectively forming $\mathrm{CO}$ from $\mathrm{CO}_{2}$ in acetonitrile with similarly low overpotentials. ${ }^{\mathbf{1 3 , 1 4}}$ We note that the thermodynamic $\mathrm{CO}_{2}$-reduction potential in common ionic liquids have been recently reported to be comparable to the value measured in $\mathrm{CH}_{3} \mathrm{CN}^{36}$

- Remarkable selectivity for $\mathrm{CO}_{2}$ reduction over $\mathrm{H}_{2}$ evolution, high faradaic yield (90\%) for the production of formic acid and significant stability upon turnover are observed under optimized conditions. Metallic electrodes have been previously extensively studied under alkaline aqueous conditions and some of them $(\mathrm{Sn}, \mathrm{Bi}, \ldots)$ display similar selectivities for the production of formic acid. ${ }^{37}$ By contrast, $\mathrm{CO}_{2}$ reduction at metallic copper electrodes is known not to be as selective, whatever the nature of the electrolyte. ${ }^{37}$ For example, metallic copper and $\mathrm{Cu}_{2} \mathrm{O}$ electrodes assayed under $\mathrm{DMF} / \mathrm{H}_{2} \mathrm{O}$ conditions (Fig. $\mathrm{S} 7 \dagger$ ) show lower selectivity for $\mathrm{CO}_{2}$-derived product as compared to the blue material, confirming previous studies carried out in $\mathrm{MeOH} .{ }^{15}$ We thus report here on the first $\mathrm{Cu}$ - 
based material displaying a high selectivity for formate production.

- The current density measured at $\eta=540 \mathrm{mV}$ is about $1 \mathrm{~mA} \mathrm{~cm}^{-2}$, which compares well to the activity of other $\mathrm{Cu}$ based materials recently reported. ${ }^{38,39}$ Routes towards higher current densities, allowing for a cost-effective process, include nanostructuration of the catalytic layer as recently demonstrated for tin-based electrodes. ${ }^{\mathbf{4 0}, 41}$ Furthermore, the importance of the organic ligand derived from the precursor, even though its exact function is still ill-defined, provides another opportunity for optimization.

\section{Methods}

\section{Preparation of $[\mathrm{Cu}(\text { cyclam })]^{2+}$ solution}

$\mathrm{Cu}\left(\mathrm{ClO}_{4}\right)_{2} \cdot 6 \mathrm{H}_{2} \mathrm{O}(19.6 \mathrm{mg}, 53 \mu \mathrm{mol})$ was added to the solution of cyclam (10.4 mg, $53 \mathrm{mmol}$ ) in DMF $(38.8 \mathrm{~mL})$. Deionized water $(1.2 \mathrm{~mL})$ was added to the above solution to obtain DMF solutions with $3 \%$ water and $1.3 \mathrm{mM}[\mathrm{Cu}(\text { cyclam })]^{2+}$. Then $n-\mathrm{Bu}_{4} \mathrm{BF}_{4}$ $(1.316 \mathrm{~g})$ was added to obtain $0.1 \mathrm{M}$ electrolytic solutions. Solutions of $\left[\mathrm{Cu}(\text { terpy })_{2}\right]^{2+}$ and $[\mathrm{Cu}(\mathrm{TACN})]^{2+}$ were prepared similarly from the corresponding ligands.

\section{Preparation of blue material}

Films of the blue material were grown on FTO electrode by controlled-potential electrolysis of freshly prepared $[\mathrm{Cu}(\text { cyclam })]^{2+}$ solutions in $\mathrm{DMF}+3 \%$ water (see above, $6 \mathrm{~mL}$ ) saturated with $\mathrm{CO}_{2}$ $\left(\mathrm{CO}_{2}\right.$ was continuously bubbled through the solution during electrodeposition). The electrolysis was typically performed at $-2.0 \mathrm{~V} v s . \mathrm{Fc}^{+} / \mathrm{Fc}$ until a charge of $4 \mathrm{C}$ has passed through the electrode. The blue material was then shortly immersed in fresh DMF for removing unreacted reagents on the surface.

\section{Electro-catalytic $\mathrm{CO}_{2}$ reduction assay}

Electro-reduction of $\mathrm{CO}_{2}$ was performed by applying a constant potential (typically -2.0 vs. $\mathrm{Fc}^{+} / \mathrm{Fc}$ ) to the working electrode dipped in a stirred, $\mathrm{CO}_{2}$-saturated (through constant bubbling

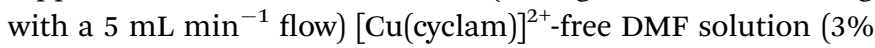
water, $0.1 \mathrm{M} n-\mathrm{Bu}_{4} \mathrm{BF}_{4}, 22 \mathrm{~mL}$ ). A distinct procedure was used for detection and quantification of $\mathrm{H}_{2}$ and $\mathrm{CO}$ : the solution was saturated (and the whole cell filled) with $\mathrm{CO}_{2}$ though initial bubbling and then isolated during the electrocatalytic $\mathrm{CO}_{2}$ assay. Some experiments have been performed with a smaller volume of electrolyte $(8 \mathrm{~mL})$ but, under such conditions, the catalytic current was less stable and the faradaic yield for production of formic acid dropped to $65 \%$.

\section{Acknowledgements}

We acknowledge support from the French National Research Agency (ANR, Carbiored ANR-12-BS07-0024-03; Labex program ARCANE, ANR-11-LABX-0003-01 and DYNAMO, ANR-11-LABX0011) and from Fondation de l'Orangerie for individual Philanthropy and its donors. We thank Jocelyne Leroy and Bruno Jousselme (CEA/DSM/IRAMIS) for XPS measurements, Matthieu Fumagalli for AFM measurements. The XAS experiments were carried out at beamline KMC-1 of the BESSY synchrotron operated by the Helmholtz Zentrum Berlin (HZB); we thank M. Mertin and Dr F. Schäfers (both HZB) for their support. JH and HD gratefully acknowledge financial support by the Berlin cluster of excellence on Unifying Concepts in Catalysis (UniCat).

\section{References}

1 A. M. Appel, J. E. Bercaw, A. B. Bocarsly, H. Dobbek, D. L. DuBois, M. Dupuis, J. G. Ferry, E. Fujita, R. Hille, P. J. A. Kenis, C. A. Kerfeld, R. H. Morris, C. H. F. Peden, A. R. Portis, S. W. Ragsdale, T. B. Rauchfuss, J. N. H. Reek, L. C. Seefeldt, R. K. Thauer and G. L. Waldrop, Chem. Rev., 2013, 113, 6621-6658.

2 C. Costentin, M. Robert and J. M. Saveant, Chem. Soc. Rev., 2013, 42, 2423-2436.

3 G. Centi, E. A. Quadrelli and S. Perathoner, Energy Environ. Sci., 2013, 6, 1711-1731.

4 E. V. Kondratenko, G. Mul, J. Baltrusaitis, G. O. Larrazabal and J. Perez-Ramirez, Energy Environ. Sci., 2013, 6, 31123135.

5 A. J. Morris, G. J. Meyer and E. Fujita, Acc. Chem. Res., 2009, 42, 1983-1994.

6 J. L. Qiao, Y. Y. Liu, F. Hong and J. J. Zhang, Chem. Soc. Rev., 2014, 43, 631-675.

7 R. Reske, M. Duca, M. Oezaslan, K. J. P. Schouten, M. T. M. Koper and P. Strasser, J. Phys. Chem. Lett., 2013, 4, 2410-2413.

8 H. Mistry, R. Reske, Z. Zeng, Z.-J. Zhao, J. Greeley, P. Strasser and B. R. Cuenya, J. Am. Chem. Soc., 2014, DOI: 10.1021/ ja508879j.

9 R. Reske, H. Mistry, F. Behafarid, B. R. Cuenya and P. Strasser, J. Am. Chem. Soc., 2014, 136, 6978-6986.

10 J. J. Wu, F. G. Risalvato, P. P. Sharma, P. J. Pellechia, F. S. Ke and X. D. Zhou, J. Electrochem. Soc., 2013, 160, F953-F957.

11 A. S. Agarwal, Y. M. Zhai, D. Hill and N. Sridhar, ChemSusChem, 2011, 4, 1301-1310.

12 D. P. Summers, S. Leach and K. W. Frese, J. Electroanal. Chem., 1986, 205, 219-232.

13 J. L. DiMeglio and J. Rosenthal, J. Am. Chem. Soc., 2013, 135, 8798-8801.

14 J. Medina-Ramos, J. L. DiMeglio and J. Rosenthal, J. Am. Chem. Soc., 2014, 136, 8361-8367.

15 K. Nakata, T. Ozaki, C. Terashima, A. Fujishima and Y. Einaga, Angew. Chem., Int. Ed., 2014, 53, 871-874.

16 Y. Oh, H. Vrubel, S. Guidoux and X. L. Hu, Chem. Commun., 2014, 50, 3878-3881.

17 M. Asadi, B. Kumar, A. Behranginia, B. A. Rosen, A. Baskin, N. Repnin, D. Pisasale, P. Phillips, W. Zhu, R. Haasch, R. F. Klie, P. Král, J. Abiade and A. Salehi-Khojin, Nat. Commun., 2014, 5, 4470.

18 C. Costentin, S. Drouet, M. Robert and J. M. Saveant, Science, 2012, 338, 90-94.

19 E. Bouwman, R. Angamuthu, P. Byers, M. Lutz and A. L. Spek, Science, 2010, 327, 313-315. 
20 C. Bucher, J. C. Moutet, J. Pecaut, G. Royal, E. Saint-Aman, F. Thomas, S. Torelli and M. Ungureanu, Inorg. Chem., 2003, 42, 2242-2252.

21 C. Bucher, J. C. Moutet, G. Pecaut, G. Royal, E. Saint-Aman and F. Thomas, Inorg. Chem., 2004, 43, 3777-3779.

22 W. Shang, X. Shi, X. Zhang, C. Ma and C. Wang, Appl. Phys. A: Mater. Sci. Process., 2007, 87, 129-135.

23 A. Paracchino, V. Laporte, K. Sivula, M. Gratzel and E. Thimsen, Nat. Mater., 2011, 10, 456-461.

24 A. V. Marenich, C. J. Cramer and D. G. Truhlar, J. Phys. Chem. $B, 2009,113,6378-6396$.

25 M. Gattrell, N. Gupta and A. Co, J. Electroanal. Chem., 2006, 594, 1-19.

26 Following the suggestion of a reviewer, we have submitted the blue material to a $30 \mathrm{~min}$ air plasma treatment in order to specifically destroy organic molecules and in particular the cyclam ligand. HPLC titration indeed indicates almost quantitative removal of the ligand from the blue material during this process. The catalytic activity is concommitantly reduced to the level of an electrode fabricated without any ligand (see Fig. S14 $\dagger$ ), in agreement with the specific role of the ligand in promoting catalysis.

27 K. L. Hu, M. Kurmoo, Z. M. Wang and S. Gao, Chem.-Eur. J., 2009, 15, 12050-12064.

28 Y. Yamada, T. Miyahigashi, H. Kotani, K. Ohkubo and S. Fukuzumi, Energy Environ. Sci., 2012, 5, 6111-6118.

29 D. Hong, J. Jung, J. Park, Y. Yamada, T. Suenobu, Y.-M. Lee, W. Nam and S. Fukuzumi, Energy Environ. Sci., 2012, 5, 76067616.
30 D. Shevchenko, M. F. Anderlund, A. Thapper and S. Styring, Energy Environ. Sci., 2011, 4, 1284-1287.

31 M. Cokoja, C. Bruckmeier, B. Rieger, W. A. Herrmann and F. E. Kuhn, Angew. Chem., Int. Ed., 2011, 50, 8510-8537.

32 D. L. DuBois, Inorg. Chem., 2014, 53, 3935-3960.

33 B. R. Galan, J. Schöffel, J. C. Linehan, C. Seu, A. M. Appel, J. A. S. Roberts, M. L. Helm, U. J. Kilgore, J. Y. Yang, D. L. DuBois and C. P. Kubiak, J. Am. Chem. Soc., 2011, 133, 12767-12779.

34 I. Niedermaier, M. Bahlmann, C. Papp, C. Kolbeck, W. Wei, S. Krick Calderón, M. Grabau, P. S. Schulz, P. Wasserscheid, H.-P. Steinrück and F. Maier, J. Am. Chem. Soc., 2013, 136, 436-441.

35 Y. Jiao, Y. Zheng, S. C. Smith, A. Du and Z. Zhu, ChemSusChem, 2014, 7, 435-441.

36 D. C. Grills, Y. Matsubara, Y. Kuwahara, S. R. Golisz, D. A. Kurtz and B. A. Mello, J. Phys. Chem. Lett., 2014, 5, 2033-2038.

$37 \mathrm{Y}$. Hori, Electrochemical $\mathrm{CO}_{2}$ Reduction on Metal Electrodes, Modern Aspects of Electrochemistry, Vol. 42, ed. G. Vayenas et al., Springer, New York, 2008, pp. 89-189.

38 C. W. Li and M. W. Kanan, J. Am. Chem. Soc., 2012, 134, 7231-7234.

39 Z. F. Chen, P. Kang, M. T. Zhang, B. R. Stoner and T. J. Meyer, Energy Environ. Sci., 2013, 6, 813-817.

40 Y. H. Chen and M. W. Kanan, J. Am. Chem. Soc., 2012, 134, 1986-1989.

41 S. Zhang, P. Kang and T. J. Meyer, J. Am. Chem. Soc., 2014, 136, 1734-1737. 